\title{
Two Novel Bacillus Strains (subtilis and simplex Species) with Promising Potential for the Biocontrol of Zymoseptoria tritici, the Causal Agent of Septoria Tritici Blotch of Wheat
}

\author{
Nora Allioui, ${ }^{1}$ Fatma Driss $\mathbb{D},{ }^{2}$ Hanen Dhouib, ${ }^{2}$ Lobna Jlail, ${ }^{3}$ Slim Tounsi $\mathbb{D},{ }^{2}$ \\ and Olfa Frikha-Gargouri $\mathbb{C}^{2}$ \\ ${ }^{1}$ Department of Ecology and Environmental Engineering, Faculty of Nature and Life Sciences and Earth and Universe Sciences, \\ University of May 8th, 1945 Guelma, Algeria \\ ${ }^{2}$ Laboratory of Biopesticides, Centre of Biotechnology of Sax, University of Sfax, P.O. Box. "1177”, 3018 Sfax, Tunisia \\ ${ }^{3}$ Analytical Services Provider Unit, Centre of Biotechnology of Sfax, University of Sfax, P.O. Box. "1177”, 3018 Sfax, Tunisia
}

Correspondence should be addressed to Fatma Driss; fatma.driss@gmail.com

Received 25 December 2020; Revised 22 April 2021; Accepted 18 May 2021; Published 29 May 2021

Academic Editor: Aqeel Ahmad

Copyright (c) 2021 Nora Allioui et al. This is an open access article distributed under the Creative Commons Attribution License, which permits unrestricted use, distribution, and reproduction in any medium, provided the original work is properly cited.

\begin{abstract}
Two novel Algerian field-collected isolates were selected for their antifungal activity against Zymoseptoria tritici (teleomorph Mycosphaerella graminicola). The novel strains, termed Alg.24B1 and Alg.24B2, were identified as Bacillus subtilis and Bacillus simplex since their respective nucleotide sequences of the $16 \mathrm{~S}$ rRNA gene were $100 \%$ and $99.93 \%$ identical to those of $B$. subtilis and B. simplex, respectively. The antifungal activities of Alg.24B1 and Alg.24B2 were evaluated by the well diffusion method and compared to those of other Bacillus species. The maximum activity was obtained after two days of confrontation of the bacterial strain supernatants with the fungus for Alg.24B1 and three days for Alg.24B2. Furthermore, the metabolites responsible for the antifungal activity of both strains were detected by the investigation of either gene presence (PCR) or molecule production (activity detection of lytic enzymes and HPLC detection of lipopeptides). Overall, this study showed that in addition to their ability to produce lytic enzymes (protease and $\beta$-glucanase), both strains coproduce three types of lipopeptides viz. surfactin, iturin, and fengycin. Thus, the biofungicide activity of both strains may be a result of a combination of different mechanisms. Therefore, they had a great potential to be used as biocontrol agents to effectively manage septoria tritici blotch of wheat (STB).
\end{abstract}

\section{Introduction}

In Algeria, wheat is the most important crop, and it is the principal consumed food, but national wheat production is very low and does not satisfy the needs of the population. Thereby, the country relies always on imports, which are increasing gradually from one year to the other. Several factors are involved in limiting wheat yields, notably, climate change, diseases, and pests, but fungal foliar diseases pose a real threat. Septoria leaf blotch of wheat (STB) caused by the heterothallic ascomycete fungus Zymoseptoria tritici (Desm.), (teleomorph Mycosphaerella graminicola (Fuckel) J. Schröt., in Cohn) [1], is one of the most devastating foliar diseases of wheat in Algeria and throughout the world. Serious epidemics can reduce the yield by 35 to $50 \%[2,3]$ via the effects of the disease on yield components and on the grain quality, which can highly decrease in infected plants [4]. In Algeria, during 2010-2012, 80\% of 160 prospected fields of durum and bread wheat in 11 localities (East, center, and west of the country), representing the major wheatproducing areas, presented the STB disease, and symptoms have reached the flag leaves of plants [5].

Different chemically synthesized fungicides are commonly used to control Z. tritici, but the pathogen has been reported to have great genetic flexibility. Consequently, fungicide-resistant strains were detected in several countries worldwide, including Algeria [6, 7]. Thus, because pesticide use becomes less socially and ecologically acceptable [8], the development of biological methods of crop protection, like the use of beneficial microorganisms (biopesticides), will 
be a benefit and one of the most promising methods for more rational and safe crop management practices [9]. Biopesticides are important for reducing the risk of resistance to chemical pesticides [10], and the majority of them are biodegradable and less toxic to humans [11] and decompose faster, resulting in lower exposure $[12,13]$.

Many microorganisms are reported as biocontrol agents and show the potential to control plant pathogens [14]. Bacillus species including B. subtilis, B. licheniformis, B. pumilus, $B$. amyloliquefaciens, B. cereus, B. mycoides, and B. thuringiensis are mostly exploited as biopesticides $[15,16]$ and are of great agriculture importance. These species are known to suppress the growth of several fungal pathogens such as Rhizoctonia, Fusarium, Sclerotinia, Sclerotium, Gaeummanomyces, Nectria, Pythium, Phytophthora, and Verticillium $[17,18]$. The first attempts to suppress $Z$. tritici were based on the use of bacteria like Pseudomonas [19] and fungi such as Trichoderma harzianum and Gliocladium roseum [20]. Later on, the potential of the genus Bacillus has been mostly investigated. For instance, the potential of B. megaterium and B. subtilis for the biocontrol of STB on wheat was reported by Kildea et al. [21] and Mejri et al. [22], respectively.

Bacillus species are a source of bioactive molecules potentially inhibitory for phytopathogen growth, among which are lipopeptides [23]. Chung et al. [24] reported that the isolate B. subtilis ME488 suppressed the growth of 39 of 42 plant pathogens tested. The main documented lipopeptides from Bacillus species are iturin [25], surfactin [26], fengycin [27], and kurstakin [28].

Moreover, Bacillus spp. produces a range of other metabolites including cell wall-degrading enzymes such as chitinases, $\beta$-glucanases, and proteases $[29,30]$. The number of antibiotics produced by the bacilli class, including the antifungal ones, was approaching 167, being 66 derived from $B$. subtilis, 23 from B. brevis, and the remaining antibiotic peptides are produced by other species of Bacillus [17].

This work aimed to identify Bacillus species endowed with antifungal activity against $Z$. tritici. The compounds responsible for the suppression of STB produced by two novel field-collected Bacillus strains were further assessed. Thus, the ability to produce antifungal metabolites (enzymes and lipopeptides) by both isolates was studied. The exploitation of their antifungal activity for their subsequent use to control the disease was discussed.

\section{Materials and Methods}

\subsection{Biological Material}

2.1.1. Fungal Material. Leaves showing symptoms of STB caused by Z. tritici (teleomorph Mycosphaerella graminicola) were taken from a naturally infected bread wheat field in Guelma (North-East of Algeria), in 2017. Isolation of the fungus was conducted according to the protocol described by Siah et al. [6]. Before use, $Z$. tritici single-spore isolates were grown on Potato Dextrose Agar (PDA, Oxide Ltd., UK) medium for 2 weeks, and then, the fungus was subcultured on PDA and grown at $20^{\circ} \mathrm{C}$ for 7 days. The suspension was prepared by scraping the surface of the culture in a $0.2 \%$
Tween 20 sterile distilled water solution and filtered through sterile cheesecloth before quantification using a Malassez counting chamber. Spore concentration was adjusted to $1 \times$ $10^{6} \mathrm{ml}^{-1}$. The latter suspension preparation method was used to prepare spore suspensions (at the same concentration) from Fusarium oxysporum, Fusarium gramineaurum, Botrytis cinerea, Aspergillus niger, and Alternaria alternata belonging to the fungal collection of the "Centre of Biotechnology of Sfax" (CBS), Tunisia.

2.1.2. Bacterial Material. Five strains of Bacillus sp. were used in this study. V26, C2, and BUPM255 belong to the bacterial collection of CBS, Tunisia. V26 is a B. subtilis strain that has a broad antifungal spectrum, including Fusarium oxysporum, Fusarium solani, Fusarium gramineaurum, Fusarium sambucinum, Botrytis cinerea, and Rhizoctonia solani [31-33]. BUPM255 is a $B$. thuringiensis strain active against Aspergillus niger, Rhizopus nigricans, Fusarium oxysporum, and Rhizopus oryzae $[34,35]$. C2 is a B. amyloliquefaciens strain that exhibits antifungal activity against Verticillium dahliae [36]. Alg.24B1 and Alg.24B2 are isolated from an Algerian soil sample taken from the rhizosphere of wheat plants in Guelma. They were selected among a collection of isolates sampled and tested for their antagonist activity towards $Z$. tritici. Strains were grown at $30^{\circ} \mathrm{C}$ using LB medium.

\subsection{Identification of Novel Strains}

2.2.1. Classical Taxonomy. The novel isolates Alg.24B1 and Alg.24B2 were identified based on the classical taxonomy criteria such as Gram coloration, oxygen dependence for growth, motility, shape, sporulation, and morphological characteristics of the colonies on LB medium.

2.2.2. Molecular Identification. The molecular methodology was carried out by $16 \mathrm{~S}$ rDNA sequencing. PCR amplification was carried out using the universal primers Fd1 ( $5^{\prime}$-AGAG TTTGATCCTGGCTCAG-3') and Rd1 ( $5^{\prime}$-AAGGAGGTG ATCCAGCC- $3^{\prime}$ ), designed from the conserved zones within the rRNA operon of E. coli [37]. The genomic DNA of the isolates Alg.24B1 and Alg.24B2, extracted from the LBcultured bacterial cells by standard protocols [38], was used as a template for PCR amplification. PCR products were purified using EZ-10 spin column DNA Gel Extraction Kit (BIO BASIC INC., Canada). Thermal cycler conditions consisted of an initial denaturation at $94^{\circ} \mathrm{C}$ for $2 \mathrm{~min}$ followed by 30 cycles; each one composed of denaturation at $94^{\circ} \mathrm{C}$ for $30 \mathrm{~s}$, annealing at $53^{\circ} \mathrm{C}$ for $1 \mathrm{~min}$, and extension at $72^{\circ} \mathrm{C}$ for $2 \mathrm{~min}$. The $1.5 \mathrm{~kb}$ amplicons were purified from the agarose gel and sequenced in an automatic sequencer (Avant Genetic analyzer, 3100 model, Applied Biosystems, CA, USA). Homology search was performed using the BLAST algorithm [39] within the NCBI database (http://www.ncbi.nlm.nih .gov/BLAST/). Accession numbers obtained from GenBank for deposited partial nucleotide sequence for $16 \mathrm{~S}$ ribosomal RNA genes were MW692842.1 and MW692843.1 for Alg.24B1 and Alg.24B2, respectively. 
2.3. Antifungal Activity Assays. The antifungal activity of cellfree filtrate was evaluated by adaptation of the well diffusion method [34]. In brief, a fungal spore suspension $\left(1 \times 10^{6} \mathrm{ml}^{-1}\right.$ in $0.2 \%$ Tween) was spread on the surface of PDA and incubated at $20^{\circ} \mathrm{C}$ in the dark for $24 \mathrm{~h}$. After $48 \mathrm{~h}$ culturing time in LB medium, $100 \mu \mathrm{l}$ of the cell-free culture supernatant were placed in the center of the wells punched in the PDA plates. $100 \mu \mathrm{l}$ of LB were used as a negative control. Plates were incubated as before and the growth inhibition zones around the bacterial supernatant were evaluated. The evaluation of the antifungal activity against $F$. oxysporum, $F$. gramineaurum, $B$. cinerea, $A$. niger, and $A$. alternata was done by checking the appearance of growth inhibition zones. However, in the case of $Z$. tritici, the diameters of the growth inhibition zones were daily measured $(\mathrm{cm})$ for five days. Besides, the specific activity (UA ml${ }^{-1}$ ) was calculated for both strains, Alg.24B1 and Alg.24B2, using the serial dilution testing [40]. One arbitrary unit (AU) of the antifungal agent was defined as the amount of cell-free culture supernatant sufficient to give a zone of inhibition around the well and calculated as the reciprocal of the highest dilution factor of the sample. All experiments were conducted three times.

2.4. Effect of Proteinase $K$ on Antifungal Activity. Cell-free supernatants with antifungal activity against $Z$. tritici were incubated at $37^{\circ} \mathrm{C}$ for $1 \mathrm{~h}$ with proteinase $\mathrm{K}\left(1 \mathrm{mg} \mathrm{ml}^{-1}\right)$. The enzyme inactivation was performed by boiling for $10 \mathrm{~min}$. Supernatants without the addition of proteinase K served as a negative control. All samples were then tested for their antifungal activity against $Z$. tritici.

2.5. Lytic Enzyme Production. Protease, $\beta$-glucanase, and chitinase activities were evaluated by culturing the bacterial strains on skim milk [41], barley flour [42], and colloidal chitin agar plates [34], respectively. A clear zone around the colony after two days of incubation at $30^{\circ} \mathrm{C}$ indicated the enzymatic degradation. The plates were flooded with Congo red solution $(0.1 \%)$ for $15 \mathrm{~min}$. The appearance of halo zones was considered a positive response for lytic activity.

2.6. PCR Detection of Lipopeptide Biosynthetic Genes. Primers used in the PCR amplifications are listed in Table 1. PCR amplifications were conducted in a $50 \mu \mathrm{l}$ reaction mixture containing $50 \mathrm{ng}$ of template DNA, $10 \mu \mathrm{l}$ of $5 \mathrm{x}$ PCR buffer, $4 \mu \mathrm{l}$ of $25 \mathrm{mmoll}^{-1} \mathrm{MgCl}_{2}, 5 \mu \mathrm{l}$ of dNTP mix $\left(0.2 \mathrm{mmoll}^{-1}\right)$, $5 \mu \mathrm{l}$ of each forward and reverse primer $\left(10 \mathrm{mmoll}^{-1}\right)$, and $2 \mathrm{U}$ of Taq DNA polymerase (GoTaq, Promega, Madison, WI, USA). Thermal cycler conditions consisted of an initial denaturation step at $95^{\circ} \mathrm{C}$ for $5 \mathrm{~min}$, followed by 30 cycles of denaturation at $95^{\circ} \mathrm{C}$ for $1 \mathrm{~min}$, primer annealing at the appropriate temperature for $1 \mathrm{~min}$, and extension at $72^{\circ} \mathrm{C}$ for $1.5 \mathrm{~min}$ followed by a final extension step at $72^{\circ} \mathrm{C}$ for $7 \mathrm{~min}$. Bacillus strain 32a, which was previously identified as B. amyloliquefaciens by Ben Abdallah et al. [43], was used as a positive control.

2.7. Isolation, Identification, and Evaluation of Lipopeptides Using HPLC Analysis. The bacterial strain cultures were carried out at $30^{\circ} \mathrm{C}$, in $50 \mathrm{ml} \mathrm{LB}$, with an initial OD of 0.1 and at a rotation of $200 \mathrm{rpm}$. Cultures were harvested by centrifuga- tion at $12,000 \mathrm{rpm}$ for $15 \mathrm{~min}$ and then filtrated through a $0.22 \mu \mathrm{m}$ cut-off filter. Cell-free cultures were purified on a C18 SPE column. The eluted fractions were concentrated in vacuo and then analyzed by HPLC using as mobile phase Milli-Q water and acetonitrile. The elution was performed using a gradient of $40-100 \%$ acetonitrile $(56 \mathrm{~min}$ ) at a flow rate of $0.6 \mathrm{ml} \mathrm{min}^{-1}$. UV detection used a wavelength of $214 \mathrm{~nm}$. The elution times for the obtained groups of peaks were compared to those observed for commercial standards (Lipofabrik, Villeneuve d'Ascq, France). Lipopeptide yields were calculated by HPLC peak area based on values obtained for pure products [45]. Experiments were carried twice.

2.8. Statistical Analysis. The data were subjected to analysis using the Statistical Package for the Social Sciences (SPSS Statistics17.0; SPSS Inc., Chicago, IL, United States). The mean values among the measurements were compared using Duncan's multiple range test at the 5\% level of significance $(p=0.05)$.

\section{Results and Discussion}

A collection of Algerian bacteria originating from the rhizosphere of wheat plants were screened for antifungal activity against $Z$. tritici by plate assays using the confrontation method. Two bacterial isolates were selected as they exhibited the highest antifungal activity against $Z$. tritici amongst the bacteria of the collection. The selected isolates were termed Alg.24B1 and Alg.24B2. They were first identified, and then, their activities were evaluated by comparison with other strains. Finally, their biofungicide compounds were investigated.

\subsection{Characterization and Identification of the Novel Isolates} Alg.24B1 and Alg.24B2

3.1.1. Spectrum of Antifungal Activity. In addition to Z. tritici, the antifungal activities of both isolates were tested against several phytopathogenic fungi, especially those causing cereal diseases viz. F. oxysporum and F. gramineaurum or crop diseases in general, namely, B. cinerea, A. niger, and A. alternata. Isolate Alg.24B1 showed a larger spectrum of activity than Alg.24B2. Indeed, Alg.24B1 showed remarkable activity against all tested fungi, while the activity was lower for Alg.24B2 and was restricted to $A$. niger and $F$. gramineaurum.

3.1.2. Classical Identification. Classical taxonomic findings showed that the newly isolated bacteria Alg.24B1 and Alg.24B2 are Gram-positive, aerobic, motile, rod-shaped, and spore-forming bacteria. LB plating showed that Alg.24B1-colonies have an irregular shape, dry, flat, and irregular with serrated margins, but Alg.24B2-colonies are creamy, glossy with irregular margins, slightly raised, and umbonate. However, the diversity of the growth patterns of B. subtilis colonies can be observed, and it is related to the availability of nutrients in the agar plate [46]. Caulier et al. [47] reported that the genus Bacillus comprises 377 species (last updated in January 2019) of Gram-positive, rodshaped bacteria. Their ability to form endospores, their 
TABle 1: Primers used for PCR for gene content detection.

\begin{tabular}{|c|c|c|c|c|c|}
\hline Lipopeptide & Gene(s) & Primers & Sequences $\left(5^{\prime}-3^{\prime}\right)$ & PCR product size $(\mathrm{bp})$ & Reference \\
\hline \multirow[t]{2}{*}{ Fengycin } & \multirow[t]{2}{*}{ fenD } & FEND-F & GGCCCGTTCTCTAAATCCAT & 269 & \multirow{2}{*}[44]{} \\
\hline & & FEND-R & GTCATGCTGACGAGAGCAAA & & \\
\hline \multirow[t]{4}{*}{ Iturin } & \multirow[t]{2}{*}{$i t u D$} & ITUD-F1 & TTGAAYGTCAGYGCSCCTTT & 482 & \multirow{4}{*}{ [24] } \\
\hline & & ITUD-R1 & TGCGMAAATAATGGSGTCGT & \multirow{3}{*}{594} & \\
\hline & \multirow[t]{2}{*}{$i t u C$} & ITUC-F1 & CCССCTCGGTCAAGTGAATA & & \\
\hline & & ITUC-R1 & TTGGTTAAGCCCTGATGCTC & & \\
\hline \multirow[t]{4}{*}{ Surfactin } & \multirow[t]{2}{*}{$s f P$} & SFP-F1 & ATGAAGATTTACGGAATTTA & \multirow[t]{2}{*}{675} & \multirow{2}{*}[24]{} \\
\hline & & SFP-R1 & TTATAAAAGCTCTTCGTACG & & \\
\hline & \multirow[t]{2}{*}{$s r f$} & Srf-A F1 & AGAGCACATTGAGCGTTACAA & \multirow[t]{2}{*}{626} & \multirow{2}{*}{ [24] } \\
\hline & & Srf-A R1 & CAGCATCTCGTTCAACTTTCAC & & \\
\hline
\end{tabular}

diversity in physiological properties, as well as their capacity to produce numerous antimicrobial compounds, favor their ubiquitous distribution in soil, aquatic environments, food, and gut microbiota of arthropods and mammals.

3.1.3. Molecular Identification. Alg.24B1 and Alg.24B2 were also identified by a molecular approach. Thereby, the genomic DNA of both isolates was used as a template to amplify PCR-fragments coding for the $16 \mathrm{~S}$ rRNA. The DNA fragments were purified and sequenced. Considering the length of sequence overlap (Table 2), DNA similarity searches against bacterial databases revealed that the $16 \mathrm{~S}$ rRNA sequence of Alg.24B1 was $100 \%$ identical to B. subtilis, while that of Alg.24B2 was more than $99.93 \%$ identical to B. simplex. These results are consistent with those obtained by the classical identification. Thus, Alg.24B1 and Alg.24B2 were identified as B. subtilis and B. simplex, respectively.

The ability of B. subtilis to suppress STB was recently documented, and the compounds involved in the activity against $Z$. tritici were studied [22]. However, to the best of our knowledge, the antifungal activity of $B$. simplex has never been reported against $Z$. tritici.

3.2. In Vitro Evaluation of the Effect on Z. Tritici Growth. Antimicrobial assays using cell-free supernatants showed specific activities against $Z$. tritici of 320 and $54 \mathrm{UA} \mathrm{ml}^{-1}$ and maximum inhibitory activities at two and three days of confrontation for Alg.24B1 and Alg.24B2, respectively. Additionally, the antifungal activity of these two newly identified strains against $Z$. tritici was compared with those of Bacillus strains of different species endowed with antifungal activities listed in the materials and methods section, namely, B. amyloliquefaciens (C2), B. subtilis (V26), and B. thuringiensis (BUPM255) (see Figure S1 in the Supplementary Materials for the illustration of the confrontation test). Equal inhibition zone diameter lengths were obtained after one and two days of confrontation with Z. tritici for Alg.24B1 (B. subtilis), C2 (B. amyloliquefaciens), and V26 (B. subtilis), on the one hand, and for Alg.24B2 (B. simplex) and BUPM255 (B. thuringiensis) on the other hand. The Alg.24B1 group was more effective than that including Alg.24B2 since it showed an earlier and higher maximum of activity (Figure 1). Compared to V26, which presented the same species as Alg.24B1 (B. subti-
TABLE 2: Identification of bacteria based on $16 \mathrm{~S}$ rRNA sequence homology.

\begin{tabular}{lccc}
\hline Isolate & $\begin{array}{c}\text { NCBI strain } \\
\text { compared to }\end{array}$ & $\begin{array}{c}\text { Length of sequence } \\
\text { overlap (bp) }\end{array}$ & $\begin{array}{c}\text { Percentage of } \\
\text { homology }\end{array}$ \\
\hline Alg.24B1 & $\begin{array}{c}\text { Bacillus subtilis } \\
\text { MT645613.1 }\end{array}$ & 1309 & $100 \%$ \\
Alg.24B2 & $\begin{array}{c}\text { Bacillus simplex } \\
\text { MF977326.1 }\end{array}$ & 1343 & $99.93 \%$ \\
\hline
\end{tabular}

lis), the latter reached the maximum of activity after only two days of confrontation, while V26 reached it after four days, even though with a larger diameter than that of Alg.24B1. This could be an essential asset for a low-cost mass production bioprocess since an early production of metabolites is always desired.

In a similar context, Schwartz et al. [48] have tested the antifungal activity of these two Bacillus subspecies: B. subtilis 30VD-1 and B. simplex 30N-5 against Fusarium oxysporum and the pea pathogen Nectria haematococca. They have shown that $B$. subtilis $30 \mathrm{VD}-1$ was a robust fungal antagonist as it can reduce the fungal growth by $50 \%$ or more after 6 days of cocultivation. However, B. simplex $30 \mathrm{~N}-5$ was not an as effective antagonistic agent as strain B. subtilis $30 \mathrm{VD}-$ 1 , in part because of its reduced growth in most cocultivation media. B. simplex $30 \mathrm{~N}-5$ limited fungal radial expansion to about one-half the level of that of B. subtilis 30VD-1. Thus, the authors concluded that both strains have the potential for use in biocontrol. Likewise, we believe that our strains have the potential to be used for biocontrol. Hence, in the following section, we investigated the metabolites responsible for their antifungal activities.

3.3. Detection of Metabolites Potentially Responsible for the Antifungal Activity. Potential contributing factors to the biofungicide activity of both strains were analyzed by the investigation of either gene presence or biomolecule production.

3.3.1. Investigation of Enzymatic Activities. Three types of enzymatic activities were investigated $v i z$. chitinase, protease, and $\beta$-glucanase activities, since the corresponding lytic enzymes are known to be cell-wall degrading hydrolases 


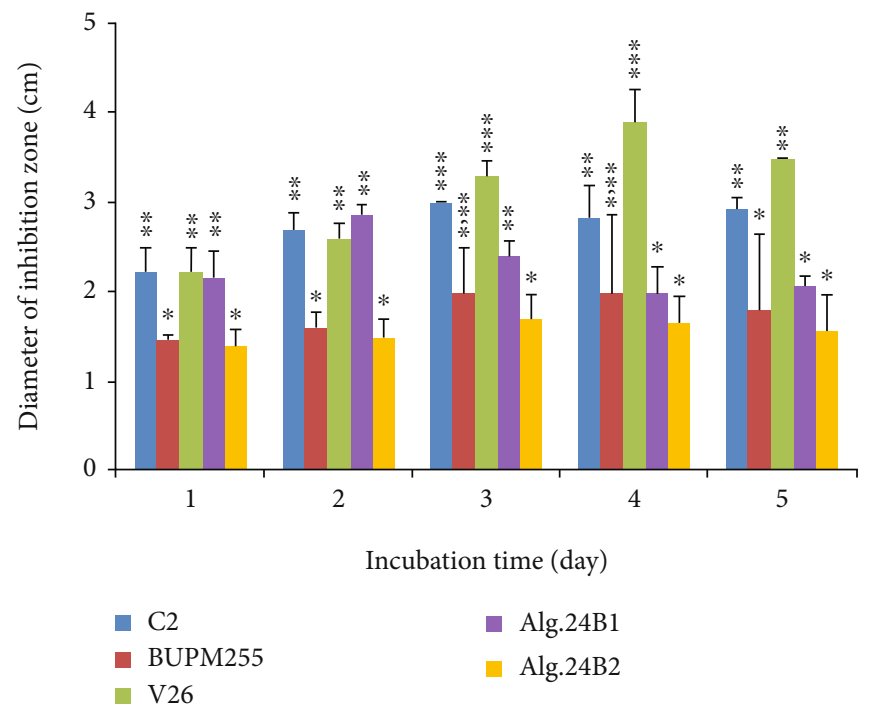

Figure 1: Effect of the Bacillus sp. strains on the in vitro growth of Z. tritici. Values were reported as means \pm SD of three measurements. Vertical bars represent standard errors of the means. “*”, “**”, and “***” show statistically significant differences between the tested Bacillus species each day separately. $p$ values less than 0.05 were considered statistically significant.

and have thus an essential role in the antifungal process [49]. Our results showed that both strains exhibited protease (Figure 2(a)) and $\beta$-glucanase (Figure 2(b)) activities, but no chitinase activity was detected at the testing conditions (Figure 2(c)). This feature is essential for the selection of these bacterial isolates to be used as biological control agents. Thus, further investigations should be carried out to characterize these enzymes.

Furthermore, the sensitivity of the respective cell-free supernatants to proteinase $\mathrm{K}$ was tested to determine if the antifungal activity produced by both strains against $Z$. tritici is only enzymatic. A slight reduction of the growth inhibition of $Z$. tritici in the presence of the supernatants treated with proteinase $\mathrm{K}$ was observed compared to the untreated ones (Figure 2(d)). This suggests that, in addition to the bioactive compounds of protein nature, both studied Bacillus strains secrete other compounds which are not of protein nature such as lipopeptides which antifungal activities are increasingly studied. Therefore, we focused on the ability of our isolates to produce lipopeptides.

3.3.2. Investigation of Lipopeptides. Last years, the antifungal activity of lipopeptides has been increasingly investigated in Bacillus species, especially in B. subtilis. Indeed, iturin produced by $B$. subtilis strains shows a broad antifungal spectrum, making it an ideal potential biological control agent [50]. Besides, surfactin A and its homologs have recently been reported to possess antifungal activity [51]. Also, fengycins produced by several $B$. subtilis strains are known to develop antifungal activity against filamentous fungi. They are responsible for membrane leakage and thus for the bioactivity of the bacterium against fungi [52]. The potential of these lipopeptides from B. subtilis [iturin (mycosubtilin), surfactin, and fengycin] has been assessed to suppress STB. A significant reduction in disease severity was found for myco- subtilin [22]. Furthermore, lipopeptides are considered natural control products that exhibit much less ecotoxicity than chemical fungicides. Therefore, we investigated lipopeptides from both isolates.

3.3.3. Molecular Investigation. To determine whether the newly identified strains have the potential to produce different types of lipopeptides, especially those with reported antifungal activities, namely, surfactin, iturin, and fengycin; nonribosomal peptide synthetase genes were investigated. This method was chosen since these genes were reported to be used as markers for the identification and selection of novel biocontrol agents from environmental samples [53, 54]. Thus, the PCR method using appropriate primers was employed, first for the detection of surfactin, iturin, and fengycin for both isolates. The ITUDF1/R1 primer pair was used to simultaneously screen for bamD, ituD, and $f e n F$, which are conserved genes that encode for malonyl-CoA transacylases involved in the biosynthesis of the lipopeptides bacillomycin D, iturin, and mycosubtilin, respectively [55]. The other primer pairs were specific for genes involved in the biosynthesis of an individual antibiotic. Amplicons of the expected sizes were obtained only with surfactin for Alg.24B1 (Figure 3). However, no amplicons were obtained for Alg.24B2 (data not shown).

Mora et al. [44] have examined the presence of the antimicrobial peptide (AMP) biosynthetic genes srfAA (surfactin), $b a c A$ (bacylisin), fenD (fengycin), bmyB (bacyllomicin), spaS (subtilin), and ituC (iturin) in 184 isolates of Bacillus strains. They found that most strains had between two and four AMP genes. The most frequent AMP gene markers were srfAA, bacA, bmyB, and fenD, and the most frequent genotypes were $\operatorname{srf} A A-b a c A-b m y B$ and $s r f A A-b a c A-$ $b m y B-f e n D$. It was suggested that "the dominance of these 

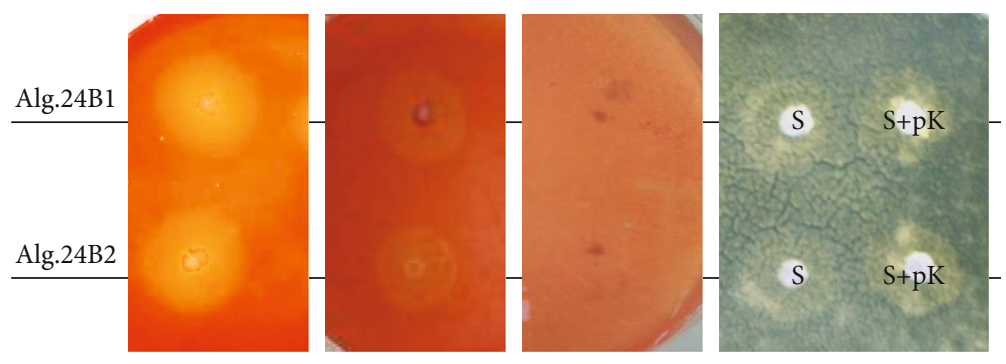

FIgure 2: Detection of enzymatic activities in strains Alg.24B1 and Alg.24B2. (a) Protease activity. (b) $\beta$-glucanase activity. (c) Chitinase activity. (d) Effect of proteinase K on the antifungal activity of both strains: S: supernatant; S+pK: supernatant treated by proteinase K.

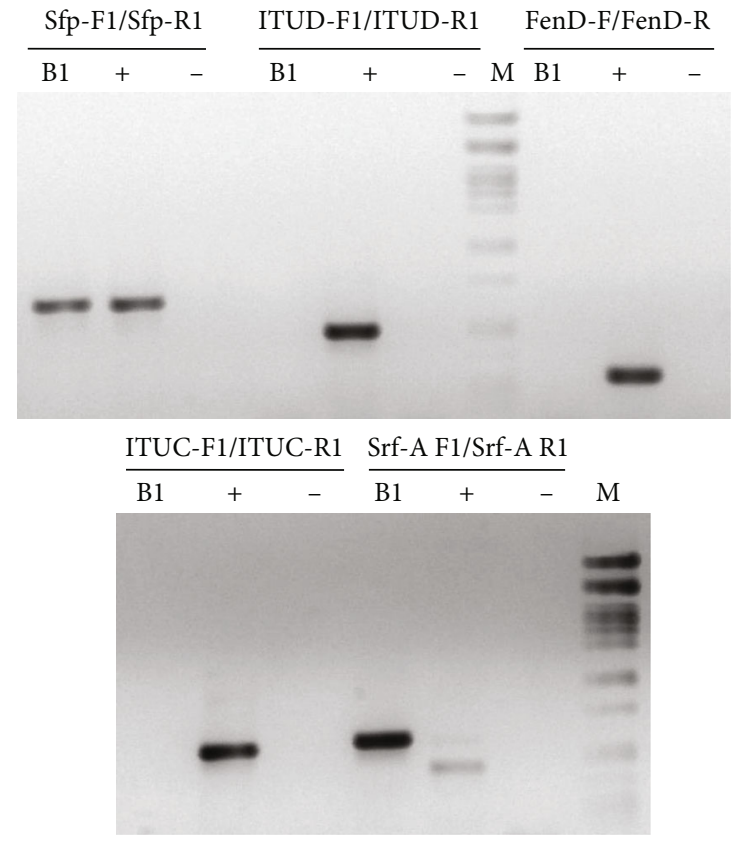

Figure 3: PCR results for Alg.24B1 strain (B1). (+) positive control, (-) negative control, (M) DNA marker: Lambda/PstI.

particular genes in Bacillus strains associated with plants reinforces the competitive role of surfactin, bacyllomicin, fengycin, and bacilysin in the fitness of strains in natural environments."

(1) Biochemical Investigation. In a second step, the lipopeptides from both strains were partially purified by SPE on a C18 column and then chromatographically separated by HPLC in reverse phase on a C18 column (Figure 4). Data analysis was carried out by comparing crop profiles with standards. For the strain Alg.24B1, the iturin family was detected at three retention times of 4.941, 5.728, and 7.064, the fengycin family was observed at one retention time of 37.249 , and the surfactin one was obtained at two retention times of 62.089 and 63.556 (Figure 4(a)). A similar profile was obtained for the strain Alg.24B2: four retention times of $4.907,5.734,6.804$, and 7.061 for the iturin family, one retention time of 37.256 for the fengycin family, and two retention times of 62.074 and 63.530 for the surfactin one (Figure 4(b)).
No correlation between genes and products of the two potent strains was observed. Indeed, although iturin and fengycin were produced by Alg.24B1, no PCR amplification of the corresponding genes was obtained. Only the surfactin family was detected in this strain by both molecular (PCR) and biochemical (HPLC) methods. Moreover, even though no PCR amplification was obtained for Alg.24B2, all lipopeptide families were detected in the HPLC retention profile of the strain. Similar results dealing with a low correlation between PCR and HPLC outcomes were reported. For example, Mora et al. [54] faced this problem while studying the bmyB and srfAA genes and their corresponding products. Besides, FrikhaGargouri et al. [56] have obtained the same trouble while studying these same genes. The main conclusions advanced on this point were that this low correlation is attributed to mutations [56] and the differential production of lipopeptides according to the growth medium used $[57,58]$.

Both strains could be considered amongst the few strains that produce more than one type of lipopeptide. According to Wu et al. [51], most Bacillus sp. can produce one type of lipopeptides and a few can produce two or three types of lipopeptides. Moreover, Sandrin et al. [59] have tested 13 strains of $B$. subtilis for the coproduction of surfactin and iturin. They found that only one strain (B. subtilis S499) produced both lipopeptides with a high yield. Pyoung et al. [60] reported that B. subtilis CMB32 produced three types of antifungal lipopeptides (Iturin A, fengycin, and surfactin A).

The mode of action of lipopeptides along the antifungal process is not clearly established. It is the subject of several investigations. Indeed, Le Mire et al. [61] showed that, by in vivo test, surfactin from the strain B. amyloliquefaciens S499 protected wheat by $70 \%$ against $Z$. tritici, but in vitro biocidal assays revealed no antifungal activity of surfactin towards the pathogen. They concluded that surfactin significantly induced wheat natural defense by stimulating both salicylic acid- and jasmonic acid-dependent signaling pathways. Mejri et al. [22] suggested that iturin has an antifungal property, but surfactin and fengycin had no direct activity on the pathogen and act on wheat against $Z$. tritici as resistance inducers rather than as biofungicides. Moreover, the biological activities of lipopeptides are closely related to the sequence of amino acid residues, the cyclization of the peptide, and the length and branching of the fatty acid chain [51]. 


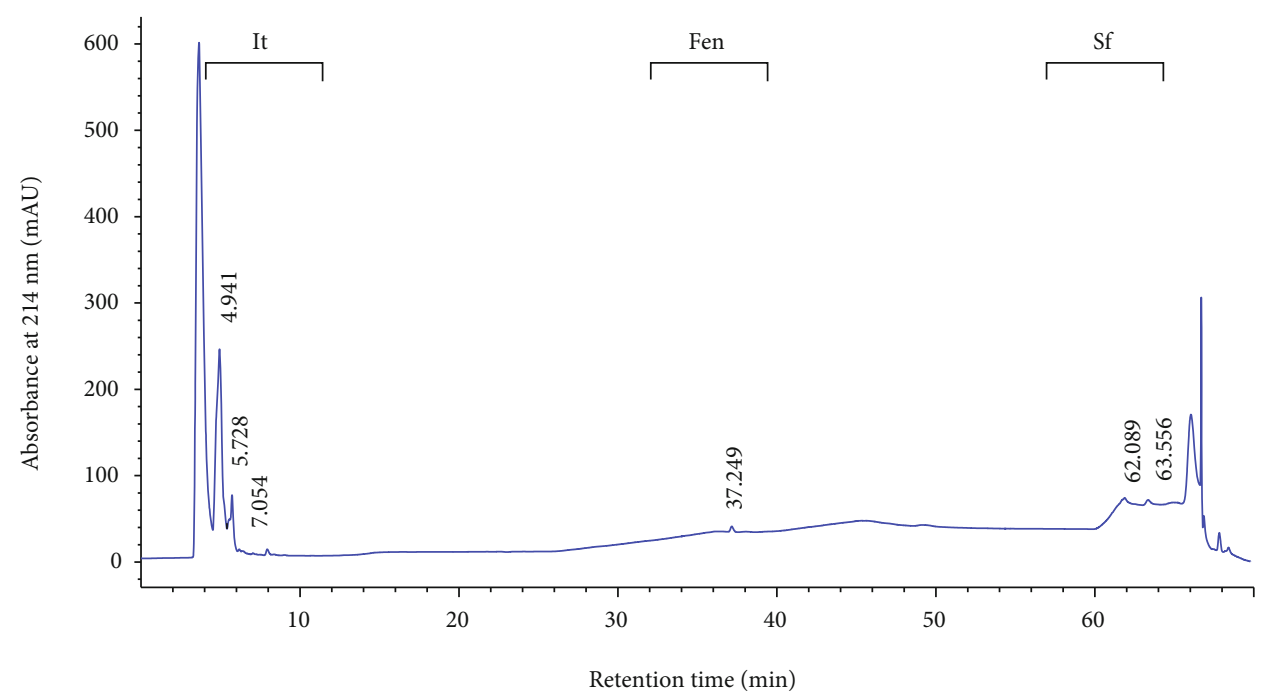

(a)

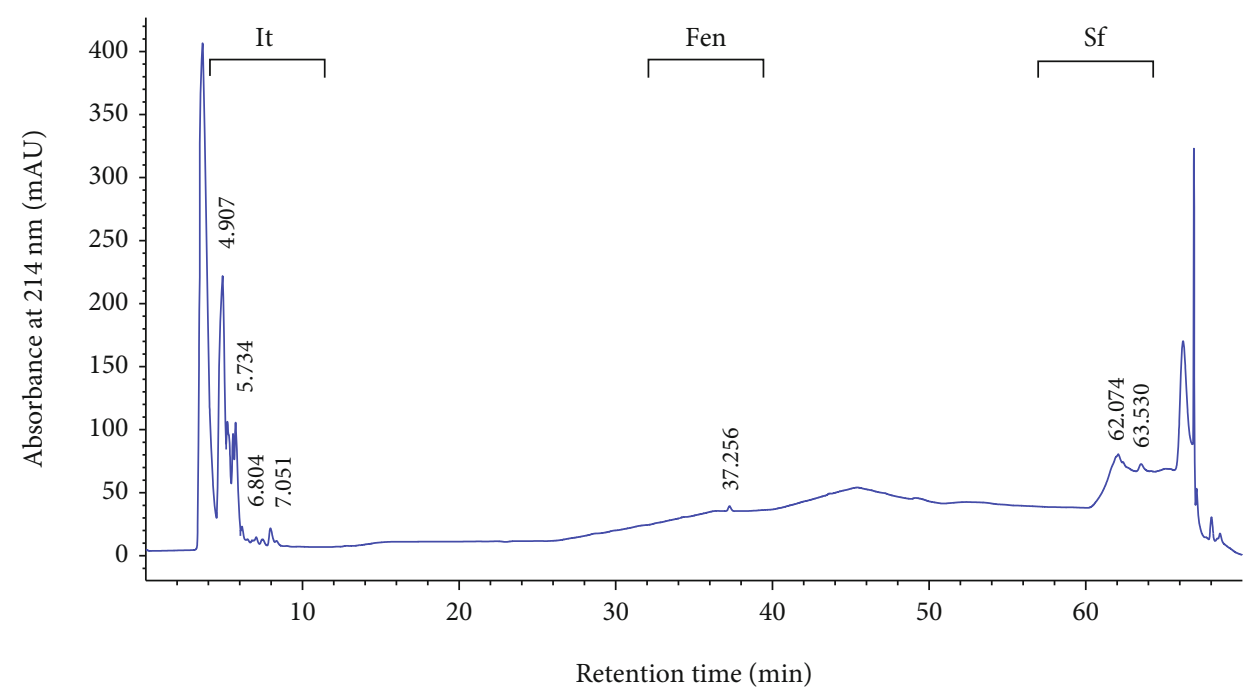

(b)

Figure 4: Chromatogram of the HPLC analysis of purified extracts from Alg.24B1 (a) and Alg.24B2 (b). Peaks corresponding to iturin (It), fengycin (Fen), and surfactin (Sf) are indicated.

The evaluation of the lipopeptide yields from both strains was carried out by HPLC (Table 3). A large amount of iturin was produced by Alg.24B1 $\left(3120 \mathrm{mgl}^{-1}\right)$. However, this quantity is not optimal and an optimized medium could be used for higher yields. Indeed, higher quantities were reported for B. subtilis strain RB14 which produces $4450 \mathrm{mgl}^{-1}$ and $5050 \mathrm{mgl}^{-1}$ of iturin by submerged fermentation and by biofilm fermentation using maltose and fish protein as sources of carbon and nitrogen, respectively [62]. Habe et al. [63] reported that the culturing conditions such as the culture medium, aeration rate, and agitation speed are crucial factors in the metabolite production process in general, and especially that of iturin from $B$. subtilis. The surfactin yield produced by Alg.24B1 was $128.17 \mathrm{mgl}^{-1}$, which is similar to that reported by Sandrin et al. [59], and Hsieh et al. [64] (110 $\mathrm{mgl}^{-1}$ and $125,6 \mathrm{mgl}^{-1}$, respectively). Mohammadipour et al. [65] have reported that B. subtilis produces from 55 to $1610 \mathrm{mgl}^{-1}$ of surfactin. According to Zhi et al. [66],
TABle 3: Yield evaluation of lipopeptides from Alg.24B1 and Alg.24B2.

\begin{tabular}{lccc}
\hline Yield $\left(\mathrm{mgl}^{-1}\right)$ & Iturin & Fengycin & Surfactin \\
\hline Alg.24B1 & 3120.00 & 0.42 & 128.17 \\
Alg.24B2 & 1400.00 & 0.17 & 23.42 \\
\hline
\end{tabular}

Bacillus isolates generate limited amounts of surfactin ( $<10 \%$ of their biomass), which functions as an antibiotic or as a signaling molecule in inter-/intraspecific interactions. However, overproduction of surfactin by B. amyloliquefaciens MT45 was observed at a titer of $2930 \mathrm{mgl}^{-1}$, which is equivalent to half of the maximum biomass. The amounts of fengycin produced by both strains are the lowest compared with those of iturin and surfactin (Table 3), which is in agreement with the results reported by Chowdhury et al. [67] for B. amyloliquefaciens. The amount of fengycin could be increased when special culture conditions are applied. 
Indeed, Coutte et al. [68] reported that $242 \mathrm{mgl}^{-1}$ of fengycin were produced by B. subtilis ATCC 21332 with special aeration by a hollow fiber membrane air-liquid contactor (polypropylene). Likewise, an amount of $3550 \mathrm{mgl}^{-1}$ was obtained at optimal medium composition by B. subtilis F29-3 [69].

Even though Alg.24B2 produces the three types of lipopeptides, the production yields were lower than those of Alg.24B1. This could explain why Alg.24B1 has a better and wider spectrum of activity than Alg.24B2. Consequently, the degree and nature of activity are widely dependent on the concentration of lipopeptides produced by the isolate [70].

Taken together, our results showed that, on the one hand, the coproduction of iturin, fengycin, and surfactin by our novel isolates Alg.24B1 and Alg.24B2 could be a good asset for their use as biological control agents. It was reported that when different families of lipopeptides are coproduced, their interaction can become synergistic and enhances each of their respective activities [71]. On another hand, the simultaneous production of lipopeptides and cell wall degrading enzymes viz. $\beta$-glucanase and protease could be a second asset for the exploitation of these potentialities for Z. tritici biocontrol. Indeed, the theory speculating that more than one mechanism could be act synergistically to suppress the disease in some specific plant-pathogen systems has been given [72].

\section{Conclusion}

The present study demonstrated the potential of two novel strains Alg.24B1 (B. subtilis) and Alg.24B2 (B. simplex) to be used as biocontrol agents on wheat against $Z$. tritici. More interest should be given to Alg.24B1 since it exhibits a wider spectrum of antifungal activity and higher yields of three types of lipopeptides (iturin, surfactin, and fengycin). The simultaneous production of three types of lipopeptides added to the production of lytic enzymes reported to be antifungal metabolites could be a good asset to the use of our new isolates for the suppression of STB. Therefore, further in vivo tests should be carried out to evaluate the potential of the isolates to be used as biocontrol. Besides, studies are to be undertaken for the identification and characterization of the produced lipopeptides from both strains since the biological activities of lipopeptides strongly depend on their structures. Finally, we believe that optimized culture conditions and formulations of these novel isolates, especially Alg.24B1, should be developed for effective biocontrol of $Z$. tritici, and eventually other phytopathogenic fungi.

\section{Data Availability}

The figures used to support the findings of this study are included within the supplementary information file named "Figure S1."

\section{Conflicts of Interest}

The authors declare that there is no conflict of interest regarding the publication of this paper.

\section{Acknowledgments}

This research did not receive any specific grants from funding agencies in the public or commercial sectors. It is supported by the SNV \& STU Faculty of May $8^{\text {th }} 1945$, University of Guelma (Algeria) and the Ministère de l'Enseignement Supérieur et de la Recherche Scientifique (Tunisia).

\section{Supplementary Materials}

Figure S1: An illustration of the antifungal activity against $Z$. tritici by adaptation of the well diffusion method. $100 \mu \mathrm{l}$ of $48 \mathrm{~h}$-cell-free filtrates of the bacterial strains were used. Photos were taken after two days of confrontation with $Z$. tritici. (Supplementary Materials)

\section{References}

[1] W. Quaedvlieg, G. H. J. Kema, J. Z. Groenewald et al., "Zymoseptoria gen. nov.: a new genus to accommodate Septoria-like species occurring on graminicolous hosts," Persoonia, vol. 26, no. 1, pp. 57-69, 2011.

[2] A. Ponomarenko, S. B. Goodwin, and G. H. J. Kema, "Septoria tritici blotch (STB) of wheat," APS net, 2011.

[3] H. Fones and S. Gurr, "The impact of Septoria tritici Blotch disease on wheat: an EU perspective," Fungal Genetics and Biology, vol. 79, pp. 3-7, 2015.

[4] A. C. Castro and M. R. Simon, "Effect of tolerance to Septoria tritici blotch on grain yield, yield components and grain quality in Argentinean wheat cultivars," Crop Protection, vol. 90, pp. 66-76, 2016.

[5] N. Allioui, Diversité génétique et structure de la population algérienne de Zymoseptoria tritici / Mycosphaerella graminicola, agent causal de la septoriose du blé. Doctoral Thesis in Plant Biology, Badji Mokhtar University, Annaba, 2015.

[6] A. Siah, C. Deweer, E. Morand, P. Reignault, and P. Halama, "Azoxystrobin resistance of French_Mycosphaerella graminicola_ strains assessed by four_in vitro_bioassays and by screening of G143A substitution," Crop Protection, vol. 29, no. 7, pp. 737-743, 2010.

[7] N. Allioui, A. Siah, L. Brinis, P. Reignault, and P. Halama, "Identification of QoI fungicide-resistant genotypes of the wheat pathogen Zymoseptoria tritici in Algeria," Phytopathologia Mediterranea, vol. 55, no. 1, pp. 89-97, 2016.

[8] C. Damalas and I. G. Eleftherohorinos, "Pesticide exposure, safety issues, and risk assessment indicators," International Journal of Environmental Research and Public Health, vol. 8, no. 5, pp. 1402-1419, 2011.

[9] D. R. Fravel, "Commercialization and implementation of biocontrol," Annual Review of Phytopathology, vol. 43, no. 1, pp. 337-359, 2005.

[10] J. Pretty and Z. P. Bharucha, "Integrated pest management for sustainable intensification of agriculture in Asia and Africa," Insects, vol. 6, no. 1, pp. 152-182, 2015.

[11] E. Siwak, M. Jewgiński, and I. Kustrzeba-Wójcicka, "Biological activity of surfactins - a case of a biosurfactant produced by Bacillus subtilis PCM 1949," Acta Biochimica Polonica, vol. 62, no. 4, pp. 875-878, 2015.

[12] S. K. Dara, Biopesticides and Integrated Pest Management, Strawberries and vegetables. eJournal on production and pest management practices for strawberries and vegetables, 2018. 
[13] D. Ndolo, E. Njuguna, C. O. Adetunji et al., "Research and development of biopesticides: challenges and prospects," Outlooks on Pest Management, vol. 30, no. 6, pp. 267-276, 2019.

[14] H. Cawoy, W. Bettiol, P. Fickers, and M. Ongena, Bacillusbased biological control of plant diseases, Pesticides in the modern world-pesticides use and management, 2011.

[15] J. Deravel, F. Krier, and P. Jacques, "Les biopesticides, compléments et alternatives aux produits phytosanitaires chimiques (synthèse bibliographique)," Biotechnologie, Agronomie, Société et Environnement, vol. 18, no. 2, pp. 220-232, 2014.

[16] P. N. Kumar, T. H. Swapna, M. K. Khan, R. Reddy, and B. Hameeda, "Statistical optimization of antifungal iturin A production from Bacillus amyloliquefaciens RHNK22 using agro-industrial wastes," Saudi Journal of Biological Sciences, vol. 24, no. 7, pp. 1722-1740, 2017.

[17] F. D. Hernández-Castillo, F. Castillo-Reyes, G. GallegosMorales, R. Rodríguez-Herrera, and C. Aguilar, "Biological Control of Root Pathogens by Plant-Growth Promoting Bacillus spp," in Weed and Pest Control-Conventional and New Challenges, S. Soloneski and M. Larramendy, Eds., pp. 79103, IntechOpen, 2013.

[18] M. Bardin, S. Ajouz, M. Comby et al., "Is the efficacy of biological control against plant diseases likely to be more durable than that of chemical pesticides?," Frontiers in Plant Science, vol. 6, 2015.

[19] E. Levy, Z. Eyal, and I. Chet, "Suppression of Septoria tritici blotch and leaf rust on wheat seedling leaves by pseudomonads," Plant Pathology, vol. 37, no. 4, pp. 551-557, 1988.

[20] A. Perelló, C. Monaco, and C. Cordo, "Evaluation of Trichoderma harzianum and Gliocladium roseum in controlling leaf blotch of wheat (Septoria tritici) under in vitro and greenhouse conditions," Journal of Plant Diseases and Protection, vol. 104, no. 6, pp. 588-598, 1997.

[21] S. Kildea, V. Ransbotyn, M. R. Khan et al., "Bacillus megaterium shows potential for the biocontrol of Septoria tritici blotch of wheat," Biological Control, vol. 47, no. 1, pp. 37-45, 2008.

[22] S. Mejri, A. Siah, F. Coutte et al., "Biocontrol of the wheat pathogen Zymoseptoria tritici using cyclic lipopeptides from Bacillus subtilis," Environmental Science and Pollution Research, vol. 25, no. 30, pp. 29822-29833, 2018.

[23] M. Ongena and P. Jacques, "Bacillus lipopeptides: versatile weapons for plant disease biocontrol," Trends in Microbiology, vol. 16, no. 3, pp. 115-125, 2008.

[24] S. Chung, H. Kong, J. S. Buyer et al., "Isolation and partial characterization of Bacillus subtilis ME488 for suppression of soilborne pathogens of cucumber and pepper," Applied Microbiology and Biotechnology, vol. 80, no. 1, pp. 115-123, 2008.

[25] S. Zhou, G. Liu, R. Zheng, C. Sun, and S. Wu, "Structural and functional insights into iturin W, a novel lipopeptide produced by the deep-sea Bacterium Bacillus sp. strain wsm-1," Applied and Environmental Microbiology, vol. 86, no. 21, 2020.

[26] F. Peypoux, J. M. Bonmatin, and J. Wallach, "Recent trends in the biochemistry of surfactin," Applied Microbiology and Biotechnology, vol. 51, no. 5, pp. 553-563, 1999.

[27] P. I. Kim, H. Bai, D. Bai et al., "Purification and characterization of a lipopeptide produced by Bacillus thuringiensis CMB26," Journal of Applied Microbiology, vol. 97, no. 5, pp. 942-949, 2004.

[28] Y. Hathout, Y.-P. Ho, V. Ryzhov, P. Demirev, and C. Fenselau, "A new class of lipopeptides isolated from Bacillus thuringiensis," Journal of Natural Products, vol. 63, no. 11, pp. 1492-1496, 2000.
[29] M. A. El-Bendary, H. A. Hamed, and M. E. Moharam, "Potential of Bacillus isolates as bio-control agents against some fungal phytopathogens," Biocatalysis and Agricultural Biotechnology, vol. 5, pp. 173-178, 2016.

[30] A. Schönbichler, S. M. Díaz-Moreno, V. Srivastava, and L. S. McKee, "Exploring the potential for fungal antagonism and cell wall attack by Bacillus subtilis natto," Frontiers in Microbiology, vol. 11, p. 521, 2020.

[31] K. S. Ben, O. Kilani-Feki, M. Dammak, H. Jabnoun-Khiareddine, M. Daami-Remadi, and S. Tounsi, "Efficacy of Bacillus subtilis V26 as a biological control agent against Rhizoctonia solani on potato," Comptes Rendus Biologies, vol. 338, no. 12, pp. 784-792, 2015.

[32] K. S. Ben, H. Boukedi, A. Laarif, and S. Tounsi, "Biosurfactant produced by Bacillus subtilis V26: a potential biological control approach for sustainable agriculture development," Organic Agriculture, vol. 10, no. S1, pp. 117-124, 2020.

[33] K. S. Ben, B. Mejdoub-Trabelsi, and S. Tounsi, "Biological potential of Bacillus subtilis V26 for the control of Fusarium wilt and tuber dry rot on potato caused by Fusarium species and the promotion of plant growth," Biological Control, vol. 152, p. 104444, 2021.

[34] F. Driss, M. Kallassy-Awad, N. Zouari, and S. Jaoua, "Molecular characterization of a novel chitinase from Bacillus thuringiensis subsp. kurstaki," Journal of Applied Microbiology, vol. 99, no. 4, pp. 945-953, 2005.

[35] F. Driss, Etude des activités chitinolytiques de Bacillus thuringiensis, Doctoral Thesis in Biology Engeneering, University of Sfax, Tunisia, 2008.

[36] H. Dhouib, I. Zouari, D. B. Abdallah et al., "Potential of a novel endophytic Bacillus velezensis in tomato growth promotion and protection against Verticillium wilt disease," Biological Control, vol. 139, p. 104092, 2019.

[37] V. Gurtler and V. A. Stanisich, "New approaches to typing and identification of bacteria using the 16S-23S rDNA spacer region," Microbiology, vol. 142, no. 1, pp. 3-16, 1996.

[38] J. Sambrook, E. F. Frisch, and T. Maniatis, Molecular cloning: $a$ laboratory manual, Cold Spring Harbor Laboratory Press, Cold Spring Harbor, 2nd edition, 1989.

[39] S. F. Altschul, T. L. Madden, A. A. Schaffer et al., "Gapped BLAST and PSIBLAST: a new generation of protein database search programs," Nucleic Acids Research, vol. 25, no. 17, pp. 3389-3402, 1997.

[40] F. Kamoun, H. Mejdoub, H. Aouissaoui, J. Reinbolt, A. Hammami, and S. Jaoua, "Purification, amino acid sequence and characterization of Bacthuricin F4, a new bacteriocin produced by Bacillus thuringiensis," Journal of Applied Microbiology, vol. 98, no. 4, pp. 881-888, 2005.

[41] M. R. Brown and J. H. Foster, "A simple diagnostic milk medium for Pseudomonas aeruginosa," Journal of Clinical Pathology, vol. 23, no. 2, pp. 172-177, 1970.

[42] R. M. Teather and P. J. Wood, "Use of Congo redpolysaccharide interactions in enumeration and characterization of cellulolytic bacteria from the bovine rumen," Applied and Environmental Microbiology, vol. 43, no. 4, pp. 777-780, 1982.

[43] D. B. Abdallah, O. Frikha-Gargouri, and S. Tounsi, "Bacillus amyloliquefaciens strain $32 \mathrm{a}$ as a source of lipopeptides for biocontrol of Agrobacterium tumefaciens strains," Journal of applied microbiology, vol. 119, no. 1, pp. 196-207, 2015. 
[44] I. Mora, J. Cabrefiga, and E. Montesinos, "Antimicrobial peptide genes in Bacillus strains from plant environments," International microbiology, vol. 14, pp. 213-223, 2011.

[45] D. B. Abdallah, F. Krier, P. Jacques, S. Tounsi, and O. FrikhaGargouri, "Agrobacterium tumefaciens C58 presence affects Bacillus velezensis $32 \mathrm{a}$ ecological fitness in the tomato rhizosphere," Environmental Science and Pollution Research, vol. 27, no. 22, pp. 28429-28437, 2020.

[46] H. Fujikawa, "Diversity of the growth patterns of Bacillus subtilis colonies on agar plates," FEMS Microbiology Ecology, vol. 13, no. 3, pp. 159-168, 1994.

[47] S. Caulier, C. Nannan, A. Gillis, F. Licciardi, C. Bragard, and J. Mahillon, "Overview of the antimicrobial compounds produced by members of the Bacillus subtilis group," Frontiers in Microbiology, vol. 10, 2019.

[48] A. Schwartz, I. Ortiz, M. Maymon et al., "Bacillus simplex-a little known PGPB with anti-fungal activity—alters pea legume root architecture and nodule morphology when coinoculated with Rhizobium leguminosarum bv. viciae," Agronomy, vol. 3, no. 4, pp. 595-620, 2013.

[49] I. Maksimov, R. Abizgil'dina, and L. Pusenkova, "Plant growth promoting rhizobacteria as alternative to chemical crop protectors from pathogens," Applied Biochemistry and Microbiology, vol. 47, no. 4, pp. 333-345, 2011.

[50] F. C. Hsieh, T.-C. Lin, M. Meng, and S.-S. Kao, "Comparing methods for identifying Bacillus strains capable of producing the antifungal lipopeptide iturin A," Current Microbiology, vol. 56, no. 1, pp. 1-5, 2008.

[51] S. Wu, G. Liu, S. Zhou, Z. Sha, and C. Sun, "Characterization of antifungal lipopeptide biosurfactants produced by marine bacterium Bacillus sp. CS30," Marine Drugs, vol. 17, no. 4, 2019.

[52] M. Deleu, M. Paquot, and T. Nylandery, "Effect of fengycin, a lipopeptide produced by Bacillus subtilis, on model biomembranes," Biophysical Journal, vol. 94, no. 7, pp. 2667-2679, 2008.

[53] M. N. Giacomodonato, M. J. Pettinari, G. I. Souto, B. S. Méndez, and N. I. López, "A PCR-based method for the screening of bacterial strains with antifungal activity in suppressive soybean rhizosphere," World Journal of Microbiology and Biotechnology, vol. 17, no. 1, pp. 51-55, 2001.

[54] I. Mora, J. Cabrefiga, and E. Montesinos, "Cyclic lipopeptide biosynthetic genes and products, and inhibitory activity of plant-associated Bacillus against phytopathogenic bacteria," PLoS One, vol. 10, no. 5, 2015.

[55] T. Stein, "Bacillus subtilis antibiotics: structures, syntheses and specific functions," Molecular Microbiology, vol. 56, no. 4, pp. 845-857, 2005.

[56] O. Frikha-Gargouri, A. D. Ben, I. Bhar, and S. Tounsi, “Antibiosis and bmyB gene presence as prevalent traits for the selection of efficient Bacillus biocontrol agents against crown gall disease," Frontiers in plant science, vol. 8, 2017.

[57] A. K. Mukherjee and K. Das, "Correlation between diverse cyclic lipopeptides production and regulation of growth and substrate utilization by Bacillus subtilis strains in a particular habitat," FEMS Microbiology Ecology, vol. 54, no. 3, pp. 479489, 2005.

[58] S. Fahim, K. Dimitrov, F. Gancel, P. Vauchel, P. Jacques, and I. Nikov, "Impact of energy supply and oxygen transfer on selective lipopeptide production by Bacillus subtilis BBG21," Bioresource Technology, vol. 126, pp. 1-6, 2012.

[59] C. Sandrin, F. Peypoux, and G. Michel, "Coproduction of surfactin and iturin A, lipopeptides with surfactant and antifungal properties, by Bacillus subtilis," Biotechnology and Applied Biochemistry, vol. 12, no. 4, pp. 370-375, 1990.

[60] K. Pyoung, J. Ryu, Y. H. Kim, and Y.-T. Chi, "Production of biosurfactant lipopeptides Iturin A, Fengycin, and Surfactin A from Bacillus subtilis CMB32 for control of Colletotrichum gloeosporioides," J. Microbiol. Biotechnol, vol. 20, no. 1, pp. 138-145, 2010.

[61] G. Le Mire, A. Siah, M.-N. Brisset, M. Gaucher, M. Deleu, and M. H. Jijakli, "Surfactin Protects Wheat against Zymoseptoria tritici and Activates Both Salicylic Acid- and Jasmonic AcidDependent Defense Responses," Agriculture, vol. 8, no. 1, p. 11, 2018.

[62] U. S. Zohora, M. S. Rahman, A. W. Khan, M. Okanami, and T. Ano, "Improvement of production of lipopeptide antibiotic iturin A using fish protein," Journal of Environmental Sciences, vol. 25, pp. S2-S7, 2013.

[63] H. Habe, T. Taira, Y. Sato, T. Imura, and T. Ano, "Evaluation of yield and surface tension-lowering activity of iturin A produced by Bacillus subtilis RB14," Journal of Oleo Science, vol. 68, no. 11, pp. 1157-1162, 2019.

[64] F.-C. Hsieh, M.-C. Li, T.-C. Lin, and S.-S. Kao, "Rapid detection and characterization of surfactin-producing Bacillus subtilis and closely related species based on PCR," Current Microbiology, vol. 49, no. 3, pp. 186-191, 2004.

[65] M. Mohammadipour, M. Mousivand, J. G. Salehi, and S. Abbasalizadeh, "Molecular and biochemical characterization of Iranian surfactin-producing Bacillus subtilis isolates and evaluation of their biocontrol potential against Aspergillus flavus and Colletotrichum gloeosporioides," Canadian Journal of Microbiology, vol. 55, no. 4, pp. 395-404, 2009.

[66] Y. Zhi, Q. Wu, and Y. Xu, "Genome and transcriptome analysis of surfactin biosynthesis in Bacillus amyloliquefaciens MT45," Scientific Reports, vol. 7, no. 1, 2017.

[67] S. P. Chowdhury, J. Uhl, R. Grosch et al., "Cyclic lipopeptides of Bacillus amyloliquefaciens subsp. plantarum colonizing the lettuce rhizosphere enhance plant defense responses toward the bottom rot pathogen Rhizoctonia solani," Molecular Plant-Microbe Interactions, vol. 28, no. 9, pp. 984-995, 2015.

[68] F. Coutte, D. Lecouturier, Y. S. Ait et al., "Production of surfactin and fengycin by Bacillus subtilis in a bubbleless membrane bioreactor," Applied Microbiology and Biotechnology, vol. 87, no. 2, pp. 499-507, 2010.

[69] Y.-H. Wei, L.-C. Wang, W.-C. Chen, and S.-Y. Chen, "Production and characterization of fengycin by indigenous Bacillus subtilis F29-3 originating from a potato farm," International Journal of Molecular Sciences, vol. 11, no. 11, pp. 4526-4538, 2010.

[70] M. H. Mohd Isa, M. A. H. F. Shannaq, N. Mohamed, A. R. Hassan, N. K. N. Al-Shorgani, and A. A. HamidAntibacterial activity of surfactin produced by Bacillus subtilis MSH1," Transactions on Science and Technology, vol. 4, no. 3-3, pp. 402-407, 2017.

[71] P. I. Kim, J. Ryu, Y. H. Kim, and Y. T. Chi, "Production of biosurfactant lipopeptides Iturin A, fengycin and surfactin A from Bacillus subtilis CMB32 for control of Colletotrichum gloeosporioides," Journal of Microbiology and Biotechnology, vol. 20, no. 1, pp. 138-145, 2010.

[72] L. García-Gutiérrez, H. Zeriouh, D. Romero, J. Cubero, A. de Vicente, and A. Pérez-García, "The antagonistic strain Bacillus subtilis UMAF6639 also confers protection to melon plants against cucurbit powdery mildew by activation of jasmonateand salicylic acid-dependent defence responses," Microbial Biotechnology, vol. 6, no. 3, pp. 264-274, 2013. 